\title{
CULTURAL AND EDUCATIONAL ACTIVITIES AT THE FACULTY OF FOREIGN LANGUAGES: AN INSTRUCTIVE ASPECT
}

\author{
Irina Bakhmetieva ${ }^{1 \star}$, Olga Anisimova ${ }^{2}$, Elena Vostroilova ${ }^{3}$, Natalia Khrenova ${ }^{4}$, Inessa \\ Zlenko ${ }^{5}$ \\ ${ }^{1}$ Associate Professor, Voronezh State Pedagogical University, RUSSIA, irbakh@mail.ru \\ ${ }^{2}$ Senior Lecturer, Voronezh State Pedagogical University, RUSSIA, olga58628889@yandex.ru \\ ${ }^{3}$ Associate Professor, Voronezh State Pedagogical University, RUSSIA, elenavostroilova@mail.ru \\ ${ }^{4}$ Associate Professor, Voronezh State Pedagogical University, RUSSIA, naphed@rambler.ru \\ ${ }^{5}$ Associate Professor, Voronezh State Pedagogical University, RUSSIA, inessazlenko@rambler.ru \\ ${ }^{*}$ Corresponding Author
}

\begin{abstract}
The paper considers an instructive aspect of cultural and educational activities at the university. The urgency of the research is determined by the current social conditions and the fact that the university students are prospective teachers, future educational professionals whose work consists not only in teaching per se but also in developing children's personal culture and inner potential.

The notions of cultural and educational activities are defined and paid due attention to as well as those of educational values and personal culture. Using a suite of methods indicated in the research, the authors conduct a poll among the fourth-year students of the faculty of foreign languages, Voronezh State Pedagogical University, the results of which demonstrate the students' definition and understanding of socially significant values and the students' priorities according to their rating scales of the most important socially significant values. The result interpretation shows, on the one hand, in what way university cultural and educational activities shape the students' views on life values, influence the development of the students' personality structures of consciousness and the students' competences. On the other hand, the results are indicative of the activities that the prospective educational professionals will offer schools after graduating from the university. Thus, the results of the poll encourage the university professors to "fill in the gaps", if any, in the further educational and cultural development of the prospective teachers.
\end{abstract}

The research can be of interest to university and school professionals, scholars and students.

Keywords: cultural and educational activities, university, foreign languages, pedagogy, education, instruction

\section{INTRODUCTION}

At present, cultural and educational activities at universities play a significant role. A sensitive social situation (the danger for a person to become infected with a constantly changing virus) has placed community worldwide at the crossroads and requires an adequate solution to pressing issues, the sphere of education being the case. At different times, scholars elaborated on the problems of cultural and educational activities, upbringing and vocational education of young people.

Much emphasis has been placed on the problem of cultural education in the researches of N.F. Bunakov [1], P.F. Kapterev [2]. Futhermore, A.D. Zharkov [3], T.G. Kiseleva [4], N.N. Yaroshenko [5], Cole M. [6], T.A. Shulgina [7], L.V. Almyashova [8], Z.I. Tyumaseva [9], N. Notten et al. [10] contributed immensely to the 
development of cultural and educational activities content.

Technological foundations of cultural and educational activities are considered in the works of A.D. Zharkov [3], S.S., Komissarenko [11], etc. Next, T.G. Kiseleva [4], Ya. Murzina, S.V. Kazakova [12], N.B. Krylova [13], Asch S. [14], Cowley S. [15], P. De Graf [16], G. Zaridze [17], M.G. Ballatore et al. [18], R. Costello and M. Lambert [19], V. Zagvyazinsky [20] focus on preparation for professional activity.

Cultural and educational activities, being part of education in the broad sense of the word, contribute to the effectiveness of the individual's socialization. A person, setting his/her own goal, relies on his/her idea, understanding of values. It is known that the values of upbringing - phenomena, objects, general abstract ideas containing a reference to the ideal, act as norms in any society. The values of upbringing are reflected in the individual's basic culture, which is understood as a system of beliefs, values, norms of behaviour, and lifestyle.

Fundamental national values are explicitly stated in the government documents of the Russian Federation in the field of education, one of which is the "Strategy of the development of education in the Russian Federation until 2025" (Order of the Government of the Russian Federation of May 29, 2015 No. 996-r) [21]. These values are cultivated in one's childhood, in the family, in the context of faith, love, and freedom. I.A. llyin, relying on the ideas of the German theologian F.A. Tholuck, demonstrates the importance of spiritual experience that begins with family relationships. Negligence in parental responsibilities, according to I.A. llyin, leads to a situation of careless upbringing, and hence, the instability in the state of mind. The history of mankind has witnessed epochs of atheism, shamelessness, cynicism, arrogant careerism, and total dishonour. In such eras, the family is not perceived as a value, as when spirituality is lost, a moral crisis occurs. I.A. Ilyin views spiritual love as a guarantee of a strong family, which can be available to everyone, regardless of the cultural level [22]. Thus, cultural and educational activities serve the principle of preserving and disseminating values. They penetrate into various spheres: education, politics, medicine, economics, leisure, etc.

\section{METHODOLOGY}

The authors employ a suite of methods: academic literature analysis including content analysis, modelling, annotation, monitoring the students' performance and generalisation.

\section{RESULTS}

\subsection{Socially Significant Values in the Students' Understanding}

A person's awareness of his/her own inner freedom, self-government, in the spiritual sense, in particular, leads to the individual's self-realisation, initially in the family [23]. As the first stage of the research, the graduates of the faculty of foreign languages (VSPU) were asked to identify socially significant values for themselves and to rank them. The following results were obtained.

$25.1 \%$ of those questioned view their family as a top priority; $19.25 \%$ put spiritual and moral values first; for $18.95 \%$ it is patriotism. $8.3 \%$ see their current values in education; health - $6.8 \% ; 5.4 \%$ - friendship; $4.7 \%$ life safety; $4.3 \%$ - career; $4.2 \%$ identified help, pedagogical assistance; $3 \%$ - material values. As seen from Table 1, family is important for prospective teachers. Respect for the family, in the respondents' opinion, is passed down from generation to generation, especially in small villages, where a great number of students come from.

Table 1. Socially significant values for the graduates

\begin{tabular}{|c|l|c|}
\hline № & \multicolumn{1}{|c|}{ Characteristic } & $\%$ \\
\hline $\mathbf{1}$ & Family & 25.1 \\
\hline $\mathbf{2}$ & Spiritual and moral values & 19.25 \\
\hline $\mathbf{3}$ & Patriotism & 18.95 \\
\hline $\mathbf{4}$ & Education & 8.3 \\
\hline $\mathbf{5}$ & Health & 6.8 \\
\hline
\end{tabular}




\begin{tabular}{|c|l|c|}
\hline $\mathbf{6}$ & Friendship & 5.4 \\
\hline $\mathbf{7}$ & Life safety & 4.7 \\
\hline $\mathbf{8}$ & Career & 4.3 \\
\hline $\mathbf{9}$ & Help; teachers' assistance & 4.2 \\
\hline $\mathbf{1 0}$ & Material values & 3 \\
\hline & Total & 100 \\
\hline
\end{tabular}

As the students point out, they first learned spiritual and moral values in the family, in their childhood, then at school, where they read simple poetry and short stories about their native land and nature within their social, cultural and educational environment, synthesizing, according to E.P. Belozertsev, diverse facts affecting a person's emotional, sensory sphere, as a result of which there is a craving for living knowledge. E.P. Belozertsev states that cultural and educational environment exists as an integral unit that combines professional, spiritual and social experience at the same time [23].

As for the foundations of patriotic education as written by the respondents, they stem from families as well. It is analyzed in the context of the spiritual and moral. Later, it finds its echo in pre-school, school and higher educational establishments. As E.P. Belozertsev claims [23], the meaning of life is revealed to a person through such a concept as the "homeland" (Father's Land) - a metaphorical, philosophical and cultural, integral concept of culture. So, in education, cultural and educational activities, it is necessary to take into account the spiritual manifestations of the Father's land, which, through national values, pave the way to the fundamental nature of the educational and pedagogical aspect.

Next, the students view patriotic education as their priority in the context of the individual's basic culture; $38.2 \%$ link their expectations with a future in peace, and since the development of this educational aspect is understood as a value, it is considered among the state spiritual objectives, with the joint efforts of the family, state, school, and society.

$36.4 \%$ of those asked are proud of their Motherland that carries out peacekeeping activities. $25.4 \%$ believe that patriotic education begins with the study of the culture of a small homeland, the place where a person lives. As gradually knowledge expands, the person gets acquainted with the world culture and universal human values.

The survey made it possible to find out which concepts students perceive as social and cultural values. In this way it becomes clear what values form a basis of the students' development path and how to plan cultural and educational activities at university, which are discussed further.

\subsection{Cultural and Educational Activities in the Students' Understanding}

Cultural and educational activity is based on the achievements of modern science; it contributes to the expansion of the range of knowledge and develops a scientific worldview in the context of the ideas of humanism. Prospective teachers assimilate social and cultural values, ways of behavior, activities, develop their inner spiritual, moral and personal potential, which is necessary for self-realization and selfdevelopment.

Cultural and educational activities are conceived as socially necessary activities aimed at disseminating vital information, at increasing the cultural development level of the society. In order to find further ways of developing cultural and educational activities, both as an academic subject and as various kinds of events, 3rd year students of the Faculty of Foreign Languages (VSPU) were requested to answer 3 questions:

1. How do you understand cultural and educational education?

2. How do you see peadagogical technology?

3. Name cultural and educational events of the university, in which you participated?

With respect to the first question, "How do you understand cultural and educational activities?", $68.4 \%$ of those questioned explained it as a process aimed at the formation of an integral personality in the conditions of personality-oriented educational work, taking into account universal human values, aimed at the formation 
of an active life position of a person. $21.2 \%$ of the respondents answered that cultural and educational education is social education, based on the dissemination of information important for society; $9.9 \%$ of those asked see the focus of cultural and educational education on a set of measures aimed at organizing educational activities; $0.5 \%$ of the respondents mentioned cultural and educational upbringing as a harmony of external and internal with social stability, involvement in public life.

Table 2. The students' responses to Question 1

\begin{tabular}{|c|l|c|}
\hline № & \multicolumn{1}{|c|}{ Characteristic } & \multicolumn{1}{|c|}{$\%$} \\
\hline $\mathbf{1}$ & $\begin{array}{l}\text { A process aimed at the formation of an integral personality in the conditions of } \\
\text { personality-oriented educational work, taking into account universal human values, } \\
\text { aimed at the formation of an active life position of a person }\end{array}$ & 68.4 \\
\hline $\mathbf{2}$ & social education, based on the dissemination of information important for society & 21.2 \\
\hline $\mathbf{3}$ & a set of measures aimed at organizing educational activities & 9.9 \\
\hline $\mathbf{4}$ & $\begin{array}{l}\text { cultural and educational upbringing as a harmony of external and internal with social } \\
\text { stability, involvement in public life }\end{array}$ & 0.5 \\
\hline & Total & 100 \\
\hline
\end{tabular}

Analyzing the students' answers, it can be observed that cultural and educational activities in the broad sense of the word are represented by $89.6 \% ; 10.4 \%$ see cultural and educational education in the narrow sense of the word, i.e. as a system of events organised by the educational institution. The students' wide range of interests can be explained by the fact that, starting from the first year, they are involved in educational activities, which take them beyond the limits of the academic disciplines, focusing on the depth of the worldview, and comprehension of the world culture.

Pedagogical technology as the embodiment of practical developments is essential in cultural and educational activities, since it gives a clear idea of both the stages and the result.

As indicated in the reply to question two, "How do you see pedagogical technology?", the following results were obtained: "a complex of interrelated components, including forms, methods, methods, techniques in the educational process; the integrity and sequence of actions aimed at achieving a certain result" - $64.3 \%$ of the respondents; $1.3 \%$ of $64.3 \%$ indicated "actions in the composition of technological technology aimed at achieving a certain result" (i.e., understanding pedagogical technology in the narrow sense of the word), while $63 \%$ understand this term in the broad sense of the word.

"Pedagogical technology as pedagogical art, skill, that with the help of which a teacher influences students" $30.1 \%$ of the students. Thus, we can observe a shift in the concepts of pedagogical "technology" and pedagogical "skill", since the latter is much wider than the former. This problem is observed not only in the students' understanding of the concepts under study, but also in modern scholarship where no agreement exists on this issue. "Pedagogical technology as an idea of joint pedagogical activity in the design, organization and conduct of various kinds of events" - $3.1 \%$ of the respondents; $2.5 \%$ of those asked associate pedagogical technology with information and communication technologies.

Table 3. The students' responses to Question 2

\begin{tabular}{|c|l|c|}
\hline № & \multicolumn{1}{|c|}{ Characteristic } & $\%$ \\
\hline $\mathbf{1}$ & $\begin{array}{l}\text { A complex of interrelated components, including forms, methods, methods, techniques } \\
\text { in the educational process; the integrity and sequence of actions aimed at achieving a } \\
\text { certain result }\end{array}$ & 64.3 \\
\hline $\mathbf{2}$ & $\begin{array}{l}\text { Pedagogical technology as pedagogical art, skill, that with the help of which a teacher } \\
\text { influences students }\end{array}$ & 30.1 \\
\hline
\end{tabular}




\begin{tabular}{|c|l|c|}
\hline 3 & $\begin{array}{l}\text { Pedagogical technology as an idea of joint pedagogical activity in the design, } \\
\text { organization and conduct of various kinds of events }\end{array}$ & 3.1 \\
\hline $\mathbf{4}$ & Pedagogical technology with information and communication technologies & 2.5 \\
\hline & Total & 100 \\
\hline
\end{tabular}

In question three, the results offer a diverse picture. Though the attendance of educational, cultural and educational events is voluntary, the students of the Faculty are happy to take part in them. $22.3 \%$ of the students named participation in the university festive events as their first choice. Among these events are the international festival of friendship, events dedicated to the Teacher's Day, "Business card", "Autumn festival", "Spring festival", "New Year elephant", VSPU concerts, "My pedagogical dynasty"; 2.3\% of them are international students who celebrated Novruz Bayram.

Table 4. The students' responses to Question 3

\begin{tabular}{|c|l|c|}
\hline $\mathbf{1}$ & \multicolumn{1}{|c|}{ Choracteristic } & $\%$ \\
\hline $\mathbf{1}$ & university festive events & 22.3 \\
\hline $\mathbf{2}$ & visit to VSPU museum & 22.1 \\
\hline $\mathbf{3}$ & the annual scientific and practical conference "Mitrofanovskie Chteniya." & 18.3 \\
\hline $\mathbf{4}$ & Faculty events & 17.4 \\
\hline $\mathbf{5}$ & reading contest & 9.9 \\
\hline $\mathbf{6}$ & lecture: "Ideological terrorism in the modern world" & 8.1 \\
\hline $\mathbf{7}$ & did not participate in any educational activities & 1.9 \\
\hline & Total & 100 \\
\hline
\end{tabular}

$22.1 \%$ of the prospective teachers are satisfied with their visit to VSPU museum on an excursion. $18.3 \%$ of the respondents remembered the annual scientific and practical conference "Mitrofanovskie Chteniya." $17.4 \%$ of those asked mentioned faculty events such as: "Francophonie", "Nietzsche's Club", "English Club", "the best group of VSPU", and a chess tournament. 9.9\% of the students wrote about the reading contest; $8.1 \%$ of prospective teachers view the lecture: "Ideological terrorism in the modern world" as crucial. $1.9 \%$ of students did not participate in any educational activities, for various reasons, among which: they live far from the university, and the activities are usually in the afternoon; due to illness, etc.

\section{CONCLUSION}

Based on the experience of previous years, university students strive to participate in educational cultural and moral activities, since they undoubtedly gain knowledge, develop skills, abilities, communication experience, etc.

Thus, based on theoretical and practical data on the educational aspect of cultural and educational activities in the university, conclusions can be drawn. Cultural and educational activities as their really necessary activity aimed at disseminating priority important information, at increasing the level of cultural development of society, is especially relevant at the present stage. Being a part of upbringing, cultural and educational activities contribute to the socialization of a person, which, when developing the trajectory of personal development, chooses the basic values reflected in the government documents of the Russian Federation in the field of education.

The practical part of the study shows a fairly high level of students' interest, their active participation in cultural and educational events that have an educational influence on future teachers, in whom such 
personal structures of consciousness as: motivating, collisional, reflexive, meaning-making, etc., receive further development. etc., as well as competencies: instrumental, communicative, etc. Based on the research data, we can talk about further planning of educational work, cultural and educational activities, prospects directed to the future are associated with further study of local history material (Malaya Rodina, Otchiy krai), with the subsequent expansion of the range of knowledge regarding the world culture.

\section{REFERENCE LIST}

Bunakov, N.F. (1953). Selected Pedagogical Essays.

Kapterev, P.F. (2015). The History of Russian Pedagogy.

Zharkov, A.D. (2012). The Theory. Methodology and Organization of Social and Cultural Activity.

Kiseleva T.G. (2004). Social and Cultural Activities.

Yaroshenko N.N. (2013). History and Methodology of the Theory of Social and Cultural Activity.

Cole M. (2005). Using cross-cultural psychology to design afterschool educational activities. Culture and Human Development: Research for the Social Sciences.

Shulgina, T.A., Ketova, N.A., Kholodova, K.A., Severinov, D.A. (2018). Motivating students to participate in professionally oriented events management. The Education and science journal. vol. 20(1).

Almyashova, L.V. (2014). Extracurricular work in a foreign language as a way to intensify learning. Philological science in terms of diversification of education. vol. 1.

Tyumaseva, Z. I., Orehova, I. L., Yakovleva, N. O. (2018). Adaptational stage of the professional socialization of students of pedagogical universities. The Education and Science Journal. 1 (20).

Notten, N., Lancee, B., Werfhorst, H., Ganzeboom, H. (2014). Educational stratification in cultural participation: cognitive competence or status motivation? Journal of Cultural Economics. 39. 10.1007/s10824-014-9218-1.

Komissarenko S.S. (2013). Personality Development: Concepts, Institute, Technologies.

Murzina, I. Ya., Kazakova, S.V.(2019). Perspective Directions of Patriotic Education. Education and Science Journal. vol. 2 (21).

Krylova N.B. (2000). Culturology of Education.

Asch, S. (1952). Social Psychology.

Cowley, S. (2006). Getting the Buggers to Behave.

De Graf, P. (1989). Cultural Reproduction and Educational Stratification.

Zaridze, G. (2018). On countering extremism among students. Spiritual and moral values and students: international Christmas educational readings.

Ballatore, M.G., Montanaro L., Tabacco A. (2019). Empowering talented students: an Italian experience of an enriched curriculum in engineering. International Journal of Engineering Pedagogy. vol. 3 (9).

Costello R., Lambert M. (2019). Motivational influences for higher education (HE) students. International Journal of Online Pedagogy and Course Design. vol. 1 (9).

Zagvyazinsky, V. (2016). Valuable and Orientation Foundations of Educational System of the Country. Education and Science Journal. vol. 6 (135).

Strategy of the development of education in the Russian Federation until 2025. (2015). (Order of the Government of the Russian Federation of May 29, 2015 No. 996-r)

Ilyin, I.A. (2018). The world is controlled from the nursery. Education of the soul.

Belozertsev, E.P. (2014). Returning to the theme of the trinity of national education. Philosophy of Russian education: history and modernity. 